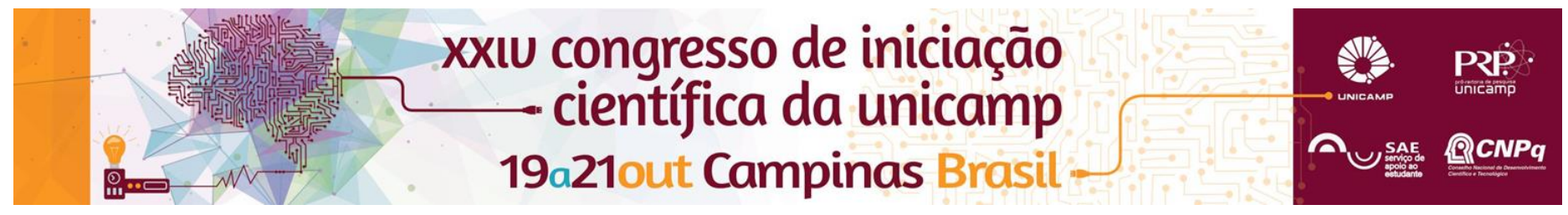

\title{
O CENTRO ESPORTIVO DE ALTO RENDIMENTO (CEAR) DE CAMPINAS-SP E AS SUAS RELAÇÕES COM OS JOGOS OLÍMPICOS DE 2016
}

\author{
PEREIRA, Fernando da Silva (IC) ${ }^{\star}$, RIBEIRO, Olívia Cristina Ferreira (PQ).
}

\begin{abstract}
Resumo
Essa pesquisa pretendeu analisar o andamento dos projetos esportivos oferecidos no CEAR e em que medida este centro se relaciona com a Política Nacional de Esporte do Ministério do Esporte. A partir dessas relações a pesquisa verificou quais as relações do CEAR com os possíveis legados/impactos dos Jogos Olímpicos de 2016 para os moradores de Campinas/SP. Para tanto, foram realizadas uma pesquisa bibliográfica, documental e de campo, por meio de entrevistas com os gestores públicos de esporte que estavam envolvidos na criação do centro.
\end{abstract}

Palavras-chave:

Megaeventos, Cear, Legados.

\section{Introdução}

Políticas públicas existem em diferentes setores da administração pública. No caso do esporte e do lazer, o órgão responsável pela formulação dessas é o Ministério do Esporte (ME), que formula e implementam programas voltados ao esporte de alto rendimento. O ME também atua para garantir o acesso gratuito à prática esportiva e de lazer para todos os cidadãos, além de ser 0 responsável pelos megaeventos esportivos como a Copa do Mundo de Futebol de 2014 e os Jogos Olímpicos (JO) de 2016. Os megaeventos estão presentes no cotidiano dos brasileiros e, de acordo com alguns autores, apresentam um grande número de público, expressivo envolvimento financeiro, ampla cobertura televisiva, construções de instalações e impactos sobre o sistema econômico e social da sociedade anfitriã. Desta forma, o Governo Federal resolveu investir na preparação do Brasil para esses megaeventos e construiu centros esportivos pelo país. Essa pesquisa teve como objetivo identificar qual a relação do Centro Esportivo de Alto Rendimento de Campinas/SP (CEAR) com a Política Nacional de Esporte (PNE) e os com os possíveis legados/impactos dos Jogos Olímpicos de 2016 para os campineiros.

\section{Resultados e Discussão}

Foi realizada uma pesquisa de cunho qualitativo, com pesquisa bibliográfica, documental e de campo. Nessa foram entrevistados dois gestores e um ex-gestor da Prefeitura Municipal de Campinas/SP envolvidos no processo de criação e funcionamento do CEAR, das áreas de esporte e turismo. As entrevistas trouxeram dados sobre a criação e o funcionamento do CEAR, uma vez que não existem documentos e legislações especificas para o centro. Sobre a função do CEAR eles afirmaram que é um centro voltado para 0 alto rendimento, entretanto questionam a falta de direcionamento do $\mathrm{ME}$, que forneceu recursos para a construção da pista de atletismo, já está finalizada e para a construção do ginásio esportivo e alojamento, estes ainda não foram construídos. O centro ainda conta com parque aquático construído de uma contrapartida social e subtilizado apenas a piscina, pois o trampolim de saltos ornamentais não foi construído como no projeto e o mesmo aconteceu com as quadras de tênis.
De acordo com Preuss (2007, p.23), o CEAR apresenta legados físicos/ambientais positivos como a utilização da pista de atletismo pelo Instituto Vanderlei Cordeiro de Lima com ORCAMPI e o uso da piscina pela APANC. Sobre os legados políticos/administrativos, pode-se afirmar que o CEAR trouxe mais visibilidade para os campineiros internacionalmente. Entretanto, os legados negativos surgiram com a falta de uma política específica para o seu funcionamento. Os gestores levantaram que a troca de secretários de esporte prejudicou 0 andamento de criação de políticas públicas para o centro, que permanece sem um modelo de gestão e sem receber nenhuma delegação esportiva internacional no preparo para os $\mathrm{JO}$, quando faltava cerca de 40 dias para o início do megaevento.

Figura 1. Mapa do Centro Esportivo de Alto Rendimento

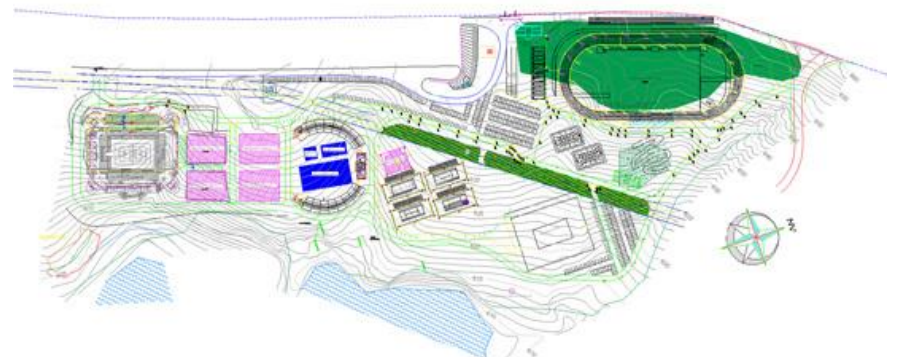

\section{Conclusão}

A falta de clareza na PNE voltada para o CEAR prejudicou no andamento de suas atividades esportivas e também na criação de um modelo de gestão.

Entretanto, ele é utilizado por algumas entidades esportivas de Campinas/SP, mas não foi possível verificar amplas relações do centro com os JO de 2016.

\section{Agradecimentos}

À professora Dra. Olívia Ribeiro, aos gestores entrevistados e ao SAE/Unicamp pelo suporte e bolsa.

CAMPINAS. Prefeitura Municipal. Secretaria de Esportes e Lazer. Disponível em: <www.campinas.sp.gov.br> Acesso em 05.Maio.2016

PREUSS, H. Aspectos Sociais dos Megaeventos Esportivos. In: RUBIO, K (Org.). Megaeventos esportivos, legado e responsabilidade social. São Paulo: Casa do Psicólogo, 2008. p. 13-35.

VILLANO, B. et all. Seminário legados de Megaeventos esportivos: pontos de convergência. In: Da COSTA, L. P. et al. (Ed.). Legados de Megaeventos Esportivos. Brasília: Ministério do Esporte, 2008. p. 47-50. 